\title{
Potret Kegagalan Asuransi Tenaga Kerja Indonesia : Perlindungan Yang Mengecewakan
}

\section{Anita Kristina $^{1^{*}}$}

${ }^{1}$ Jurusan Ekonomi Pembangunan Fakultas Ekonomi \& Bisnis Universitas Trunojoyo Madura

\section{Informasi Artikel \\ Sejarah artikel: \\ Diterima Oktober 2017 \\ Disetujui Februari 2018 \\ Dipublikasikan Maret \\ 2018}

\section{Keywords:}

Indonesian Workers Insurance Program,

Indosian Worker Protec-

tion,

Protection

\begin{abstract}
A B S TR ACT
The objective of this research is focusing on the structure of government insurance for protect the Indonesian labor. To analyse this case, the qualitative and phenomenology approach are used in this research. Data was collected deeply by interviewing the Indonesian labor and the formers Indonesian labor. The result has shown that Indonesian workers were very disappointed in the scheme of government insurance and protection. This problem is not efficiently help Indonesian workers due to economic burden in the workers, as we know that the Indonesian workers are in low economic level. Moreover, the Indonesian labor are not gained many benefits from the government insurance and protectionThe result of this research is then discussed with the policy theory and protection service that should be obtained by Indonesian workers. The changes of the insurance protection scheme of Indonesian workers became an important issue for immediate implementation to improve the quality of protection system.
\end{abstract}




\section{Pendahuluan}

TKI yang disebut sebagai pahlawan devisa, justru mereka mendapatkan perlakuan yang tidak adil di luar negeri. Persoalan yang ditemui TKI, bukan lagi persoalan terkait kualitas skill mereka, namun terkait dengan eksploitasi, kondisi kerja yang buruk dan terabaikannya upah (Usman, 2007), rentan terhadap masalah saat di negara tujuan (Suharto, 2013), penyiksaan oleh majikan (Azmy, 2012), pemutusan hubungan kerja (PHK), kecelakaan kerja, gaji tidak dibayar, pelanggaran kontrak kerja, pelecehan seksual, pemerkosaan, meninggal dunia, TKI hilang, kerja di bawah umur, dan kerja tidak sesuai kesepakatan kontrak kerja. Kondisi kerja dan persoalan pada pekerja ini rentan menjadi eksploitasi, yaitu tidak adanya toleransi hak, perlindungan kesehatan dan keselamatan kerja yang buruk (ILO, 2012). Dengan tingkat pengaduan sebanyak 2.111 kasus (Januari-Mei 2017). Lebih ironis lagi, jumlah TKI tiap tahun mengalami kenaikan. Jumlah TKI saat ini sebanyak 83.900 orang (Januari-Mei 2017). Jumlah TKI tiap tahun naik, berdampak pada kenaikan devisa tiap tahun. Meskipun demikian, kontribusi tersebut dibayar TKI dengan resiko kerja yang dapat mengancam/membahayakan keselamatan, kesehatan dan kesejahteraan TKI, sehingga pemerintah memberikan perlindungan untuk TKI.

Pemerintah berkewajiban memberikan perlindungan, yaitu sesuai ketentuan dalam Undang-Undang No. 39 tahun 2004 tentang penempatan dan perlindungan tenaga kerja Indonesia di luar negeri bahwa pemerintah bertugas mengatur, membina, melaksanakan, dan mengawasi penyelenggaraan, penempatan, dan perlindungan TKI di luar negeri. Perlindungan TKI sebagai alternatif untuk menciptakan kemanfaatan bagi individu yang berpusat pada pemerintah, bukan hanya persoalan hukum, namun pada kebermanfaatan program, sehingga dibutuhkan upaya modifikasi yang relevan tanpa meninggalkan ketentuan hukum, salah satunya melalui skema asuransi (Simitsia \& Kallopi, 2014).

Begitu juga perlindungan pemerintah pada TKI diberikan dalam bentuk skema asuransi. Pemberian asuransi sebagai kewajiban bagi calon TKI, dibayarkan saat mereka belum berangkat ke luar negeri. Berlaku pada masa pra penempatan, masa penempatan, dan purna penempatan. Besar biaya asuransi ini sebesar Rp. 400.000,-. Namun, skema asuransi TKI ini masih belum mampu melindungi TKI secara utuh. Karena masih memberikan perlindungan sebatas perlindungan finansial yang diberikan. Belum mampu memberikan perlindungan TKI yang menghargai hak asasi TKI sebagai manusia. Artinya, bahwa TKI patut memperoleh perlindungan yang tidak hanya bicara pada tataran hukum, tapi lebih fokus pada penempatan TKI sebagai manusia seutuhnya dan subjek pada perlindungan tersebut (Ciuca, 2014).

Berbagai persoalan yang dihadapi TKI, menjelaskan secara tidak langsung bahwa kerangka perlindungan yang diberikan pemerintah masih menyisahkan banyak persoalan. Dengan demikian, berbagai hal yang terjadi menunjukkan ketidaksiapan pemerintah dalam menghadapi situasi yang semakin dinamis, ketidakseriusan pemerintah dalam menyediakan asuransi sebagai kebijakan perlindungan. Sehingga perlu dicermati dan diketahui bagaimana sesungguhnya kerangka perlindungan TKI (dalam perspektif TKI).

\section{Metode Penelitian}

Penelitian ini menggunakan analisis femenologi dengan perspektif teori kelembagaan. Pengumpulan data dilakukan melalui interview ekslusive dengan $\mathrm{TKI}$, mantan TKI, yang berasal dari Jawa Timur. Teknik analisis menggunakan induktif, dengan uji validitas triangulasi. 
Hasil dan Pembahasan

Identifikasi Kerangka Perlindungan Asuransi TKI

Identifikasi atas kerangka

perlindungan asuransi TKI ini menurut perspektif TKI. Karena TKI sebagai subjek sekaligus objek dari perlindungan tersebut. Temuan atas identifikasi ini mengindikasikan adanya kekecewaan TKI atas pengelolaan asuransi selama ini. Jika skema asuransi belum mampu hadir menjadi manfaat bagi TKI, dan justru sebagai beban yang memberatkan untuk TKI, maka selanjutnya temuan atas hal tersebut diskusikan dengan teori kelembagaan. Hasil temuan yang sebagian besar menunjukkan TKI merasa kecewa, maka dapat dipahami sebagai kegagalan perlindungan. Berikut temuan atas hasil identifikasi dan diskusi atas temuan tersebut :

\section{Biaya Asuransi Memberatkan TKI}

Beban biaya yang ditanggung oleh calon TKI/TKI bukan menjadi hal yang mudah bagi TKI. Karena memilih untuk berangkat ke negara lain bukan sebuah pilihan biasa. Banyak dari mereka berangkat dengan alasan kemiskinan, atau untuk mencari kesejahteraan, namun kesejahteraan belum tentu didapat, bahkan biaya hutang atas cost structure yang harus dibayar menjadi kewajiban yang harus ditanggung. Tentu tidak mudah bagi TKI menghadapi kondisi seperti ini.

Terkait dengan proses klaim yang banyak menggunakan kesepakatan informal, maka dalam interaksinya membutuhkan biaya juga. Oleh karena itu, dimungkinkan dalam proses penyelesaian klaim asuransi, TKI juga dibebankan dengan sejumlah biaya yang harus dikeluarkan. Hal ini juga akan membebani TKI secara ekonomi.

Meskipun dalam realitasnya, TKI membutuhkan komunitas paguyuban atau keluarga untuk menyelesaikan persoalan ini. Biaya tersebut dibayar melalui bantuan oleh komunitas atau keluarga. Biasanya, jika dibantu oleh komunitas atau keluarga maka beban biaya transaksi TKI akan menjadi lebih mudah/ringan, tidak seberat jika harus dipikul sendiri atau melalui hutang. Menurut North (dalam Yustika, 2013) bahwa komunitas menyebabkan biaya transaksi rendah, artinya kedekatan hubungan di dalam sebuah komunitas atau keluarga akan membantu meringankan beban biaya atas implikasi mekanisme tata kelola terkait asuransi TKI ini. Sementara itu, struktur kekuasaan yang memposisikan TKI sebagai pihak/aktor yang tidak berdaya tawar/tidak berkuasa dalam mengambil keputusan, maka kondisi ini memunculkan konflik bagi TKI, terutama terkait biaya yang harus ia keluarkan di saat ia menginginkan haknya terpenuhi.

Ringkasnya, secara sederhana dapat dikatakan bahwa apapun yang dilakukan TKI dalam bertransaksi membutuhkan biaya, yang dibebankan di awal dan menjadi beban hutang yang harus dibayar sesuai dengan kontrak perjanjian kerja yang sudah ditandatangani. Namun, biaya yang dibebankan pada TKI ini tidak lagi merujuk pada tingkat dan batas kesanggupan TKI secara individu. Realitasnya, berapapun biayanya, TKI tetap menerima, menyimpan, memproses, bahkan banyak TKI yang berangkat lagi ke negara penempatan. Artinya, memenuhi biaya yang sebenarnya menjadi "beban" bagi dirinya adalah sebuah pilihan rasional. Karena menurut Wiiliamson (dalam Yustika, 2013) pilihan rasional membuat individu mempunyai batas kesanggupan sendiri atau kemampuan untuk memproses dan menggunakan informasi yang tersedia. Diperjelas kembali menurut Delliarnov (2006) bahwa pilihan rasional adalah individu selalu memilih tindakan terbaik sesuai keterbatasan yang dimiliki. Implikasinya, setiap pelaku TKI menjadi pelaku ekonomi yang akan menghadapi informasi tidak lengkap/ketidakpastian informasi serta beban biaya yang ditanggungnya. Mahalnya biaya yang harus ditanggung TKI mem- 
buat persoalan semakin kompleks. Tidak mungkin TKI untuk tidak membayar semua biaya. Karena pemerintah melalui bank negara penempatan telah memberikan pinjaman kepada TKI.

\section{Tidak Ada Kejelasan Berbagi Keuntungan dalam Asuransi TKI}

Sementara itu, perilaku opportunis juga hadir dalam transaksi. Artinya, ada upaya untuk mendapatkan keuntungan dari pihak lain dibalik beban TKI tersebut. Namun, laba yang didapat dari keuntungan yang bersifat keunggulan produktif (misalnya lokasi yang unik atau keterampilan yang berbeda) tidak dianggap sebagai sikap opportunis (Wiiliamson, 1996). Sedangkan sikap opportunis yang muncul dalam kesepakatan adalah adanya perilaku yang tidak jujur, karena ada informasi yang disembunyikan terkait keuntungan yang diperoleh TKI

Tidak adanya kejelasan keuntungan tersebut dipengaruhi oleh informasi yang tidak lengkap bagi TKI. Apapun yang dilakukan TKI untuk memenuhi biaya tersebut. Hal ini terjadi karena untuk memaksimumkan kepuasan yang diharapkan (kemudahan), yang sebenarnya dilakukan tanpa secara aktual melakukan perhitungan/kalkulasi, sehingga dengan demikian pemenuhan kepuasan (kemudahan) tersebut seringkali tidak terpenuhi. Melalui pemahaman ini, biaya yang dikeluarkan TKI melekat pada tindakan yang dibutuhkan. Jadi, pertukaran transaksi tersebut pada akhirnya akan menentukan seberapa besar biaya yang ditimbulkan. Ketidaktahuan TKI atas keuntungan ekonomi asuransi TKI juga menjadi kelemahan TKI.

TKI harus mencari kejelasan sendiri melalui berbagai informasi. Misalnya, penjelasan dapat diterima melalui proses PAP, atau kejelasan diterima dari PPTKIS atau informasi tersebut di cari sendiri melalui berbagai media. Namun, apapun dan bagaimanapun derajat informasi dan pengetahuan TKI tentang asuransi dan keuntungan yang ia miliki, tidak mempengaruhi keputusan asuransi yang ia buat. Artinya, TKI tetap berada pada jalur kewajiban untuk tetap membayar asuransi sebagai syarat pemberangkatan sebagai TKI. Dengan demikian, agar proses tersebut tetap berlangsung (walaupun sebagai beban) maka TKI harus bertransaksi dengan aktor lain di luar kesepakatan (asuransi), misalnya PPTKIS atau petugas rekruitmen atau pihak lain pemberi informasi. Kondisi ini juga yang menyebabkan biaya yang harus dikeluarkan semakin besar melebihi biaya yang seharusnya dibayarkan TKI. Karena semakin panjang dan kompleks jaringan transaksi maka kian banyak biaya yang muncul.

\section{Penyelesaian Ganti Rugi Asuransi Hanya di Kantor Pusat}

Selanjutnya, tantangan bagi TKI dan keluarganya saat mereka menyelesaikan persoalan asuransi yang harus menguruskan ke kantor pusat perusahaan asuransi. Karena semua kantor perwakilan tidak melayani penyelesaian asuransi, dan harus diselesaikan di kantor pusat yang ada di Jakarta. Artinya bahwa diartikan ada pihak yang menangani jika terjadi kasus atau persoalan terutama persoalan klaim asuransi. Pihak yang menangani tersebut perlu melakukan perjalanan bolak-balik ke Jakarta, dan hal tersebut membutuhkan biaya. Pihak tersebut bisa dilakukan oleh TKI atau keluarganya sendiri atau bahkan meminta fasilitas dari Dinas Tenaga Kerja Provinsi (UPT.P3TKI Jatim) atau juga ke PPTKIS.

Hal tersebut seharusnya tidak terjadi, mengingat kantor konsorsium asuransi TKI mewakili kantor perwakilan yang ada di Provinsi, tetapi untuk mendapatkan respon dari kantor perusahaan asuransi atau konsorsium asuransi TKI, TKI harus datang sendiri dan menemuinya untuk menyelesaikan persoalan asuransinya. Oleh karena itu, hal ini juga menjadi tantangan 
tersendiri bagi TKI dan pemerintah. Tantangannya adalah upaya mengurangi biaya akibat interaksi terkait kesepakatan dalam asuransi TKI. Hal ini akan tercapai jika desain kelembagaan yang dibuat mendukung interaksi tersebut sebagai sebuah layanan, yakni penyediaan informasi, melindungi hak-hak TKI dan mekanisme yang efektif. Isu ini setidaknya menjadi persoalan di tiap interaksi, karena interaksinya sangat kompleks dan syarat dengan informasi yang assimetris.

Oleh karena itu, biaya yang telah diidentifikasi tersebut disebut oleh Wiliamson (dalam Yustika, 2013) sebagai biaya adaptasi. Karena menurut Williamson, biaya adaptasi ialah biaya yang ditimbulkan ketika kesepakatan/ kontrak yang sudah terjadi mengalami perpindahan situasi sub optimal di bawah kondisi yang diharapkan, dan terdapat biaya negosiasi untuk mendapatkan informasi yang lebih baik dari pihak lain serta dimungkinkan adanya biaya arbitrasi jika ke pengadilan apabila terjadi sengketa.

Terkait upaya penyelesaian sengketa ke pengadilan, di Indonesia memiliki jaringan pengadilan yang secara nasional di bawah pengawasan Mahkamah Agung. Dalam kasus ketenagakerjaan seperti klaim asuransi ataupun persoalan lainnya, TKI juga berhak untuk melakukan gugatan terhadap pihak lain berdasarkan hukum perdata. Seperti yang diatur dalam Peraturan BNP2TKI No. 13 Tahun 2012 mewajibkan pejabat BNP2TKI untuk mengarahkan pada pihak ke pengadilan jika mereka tidak dapat menyelesaikan klaim asuransi mereka atau kasus lain. Namun, pemerintah (BNP2TKI) ini hanya memfasilitasi untuk melakukan mediasi terlebih dahulu sebelum mengarahkan ke proses pengadilan.

Tetapi menurut hasil kajian Farbenblum (2013) saat melakukan wawancara pada para pengacara terkait persoalan TKI yang di selesaikan pada pengadilan, jawabannya bahwa sistem pengadilan bukanlah pilihan yang layak bagi sebagian besar pekerja migran dalam menuntut ganti rugi. Kecenderungan yang terjadi, kasus mereka menjadi lemah bukti, karena kurangnya bukti tentang apa yang terjadi, terutama kejadian perkara ada di negara penempatan. Memahami pendapat tersebut, dapat diartikan bahwa proses pengadilan juga akan memakan biaya dan waktu. Dan untuk maju ke pengadilan, TKI juga membutuhkan perwakilan hukum dan bukti konkret. Akibatnya, sangat sedikit kasus yang melibatkan TKI yang dibawa ke pengadilan (Farbenblum ,2013).

Sebenarnya, TKI juga berhak untuk mengajukan kasus klaim atau perselisihan terkait klaim asuransi ini ke pengadilan. Pengadilan hubungan industrial umumnya menjadi sandaran TKI. UU Hubungan Industrial No. 2 Tahun 2004 menetapkan bahwa suatu proses yang awalnya mencerminkan proses dalam sistem tenagakerja migran terdapat musyawarah, dan negosiasi, diikuti oleh jalur konsiliasi atau jalur mediasi yang dilakukan oleh wakil pemerintah di Kementrian Tenaga Kerja.

Namun, dalam UU No. 2 Tahun 2004 tersebut juga membatasi bahwa pihak yang bersengketa ke dalam pihak pekerja/organisasi buruh dan pihak majikan/organisasi majikan (pasal 1), dan tidak mencakup pihak yang terlibat dalam perekrutan tenaga kerja (misal PPTKIS atau pemerintah). Dalam UU ini tidak disebutkan ruang untuk memeriksa PPTKIS atau pemerintah (Disnaker/BNP2TKI) terkait persoalan pengajuan klaim. Meskipun kesepakatan asuransi TKI bersifat individual sekali, terjadi antara TKI dan Konsorsium asuransi. Sehingga terdapat ruang yang tidak adil bagi TKI, mengingat PPTKIS dan pemerintah sebagai pihak yang memahami dengan benar proses awal dan bahkan informasi yang utuh tentang TKI. Apapun, struktur pengadilan di Indonesia, masih membuat TKI untuk berpikir ulang terkait perselisihan klaim 
asuransi. Implikasi atas kondisi ini masih terkait dengan persoalan biaya.

Kondisi lain yang melemahkan TKI, yakni terdapat pembatasan yang dicantumkan oleh KUHP (Kitab Undang-Undang Hukum Perdata) (pasal 74), terutama pembatasan mengenai klaim asuransi. Dalam KUHP tersebut pengaduan dilakukan dalam waktu enam bulan setelah "orang yang berhak mengadu mengetahui adanya kejahatan," jika berdomisili di Indonesia, atau dalam waktu 9 (sembilan) bulan jika pelapor berada di luar negeri. Selanjutnya, anggota keluarga tidak dapat mengajukan pengaduan selama TKI berada di luar negeri karena KUHP hanya mengizinkan individu yang menjadi korban saja untuk membuat pengaduan, kecuali jika yang bersangkutan masih berusia di bawah 16 tahun, maka seorang wali dapat mengajukan pengaduan (pasal 72). Dengan demikian, bagi TKI yang sering berada di luar negeri selama dua tahun atau lebih, perkara penyelesaian klaim ini akan menjadi hambatan bagi dirinya, kecuali perselisihan klaim yang terjadi di dalam negeri (saat pra penempatan dan purna penempatan). Pembatasan sistem pengadilan dan hukum di Indonesia terkait persoalan TKI ini, membawa konsekuensi bahwa pentingnya negosiasi langsung atau mediasi yang difasilitasi pemerintah.

Jika TKI menyelesaikan persoalan klaim melalui layanan resmi yang disediakan oleh UPT.P3TKI sebagai wakil dari pemerintah. Pemerintah memfasilitasi untuk mempertemukan pihak yang berkonflik, terutama jika harus menyelesaikan persoalan klaim asuransi. Perjalanan ke Jakarta memerlukan biaya mahal dan memakan waktu sehingga TKI malas untuk melakukan klaim dikarenakan biaya yang mahal ini. Belum lagi adanya prosedur yang berbelit sehingga semakin lama pengurusan klaim. Biaya akan semakin besar jika terkait dengan lamanya waktu penyelesaian klaim tersebut.

\section{Kegagalan Perlindungan Asuransi TKI}

Berdasarkan temuan sebelumnya, maka dapat dikatakan bahwa terdapat ketidakseriusan pihak terkait, apalagi PPTKIS yang dulunya mengantarkan, mendaftarkan, bahkan sebagai pihak yang diberi kuasa oleh TKI.PPTKIS yang dulunya sebagai penentu "nasib" TKI terkait asuransi TKI, namun di saat TKI membutuhkan peran mereka, PPTKIS ini tidak memperlakukan seperti awal mereka bertemu. Hal ini disebabkan adanya kepentingan yang beda. Hak-hak TKI sudah tidak dilindungi oleh PPTKIS.Hak-hak ini meliputi hak mendapatkan layanan dan informasi data yang dimiliki PPTKIS, atas pemberian kuasa yang diberikan TKI. Dengan demikian, dapat dikatakan bahwa perlindungan hakhak yang dipertukarkan juga membutuhkan biaya. Karena adanya biaya transaksi yang dipertukarkan di dalam penjaminan hak, dan membutuhkan biaya yang tidak sedikit/rendah bagi jaminan hak tersebut (Alchian\& Demsetz, 1972).

Persoalan ekonomi yang muncul menjadi beban tersendiri bagi TKI. Namun, munculnya persoalan tersebut adalah hal yang sangat wajar akibat rasionalitas. Karena menurut Williamson (1996) terdapat konsep rasionalitas yang terbatas pada tiap tindakan manusia. Terutama terkait kemampuan yang tidak sempurna yang dimiliki TKI (sebagai prinsipal) dalam memproses sejumlah informasi. Sebagai konsekuensinya adalah TKI tidak dapat mengambil keputusan yang paling tepat bahkan dalam membuat keputusan, TKI seringkali menggunakan informasi yang keliru. Hal ini juga menjadi memicu besarnya biaya yang harus dikeluarkan TKI. Dengan demikian, dapat dihubungkan antara sikap rasionalitas yang terbatas dimiliki oleh TKI dengan faktor kompleksitas atas ketidakjelasan informasi, sehingga dalam prosesnya memunculkan banyak ketidakpastian. Kompleksitas tersebut berkaitan dengan kesulitan TKI dan pemerintah dalam mengelola informasi 
yang mereka miliki. Sedangkan ketidakpastian muncul sebagai akibat dari terbatasnya kesimpulan dan keberadaan informasi yang tidak sempurna. Ketidakpastian informasi ini akan memunculkan biaya yang mahal (Grossman \& Hunt, 1983). Dalam hal ini akan memastikan bahwa aturan yang disepakati tidak akan dapat berjalan sesuai apa yang diharapkan.

Buktinya adalah saat identifikasi kerangka perlindungan diketahui bahwa terdapat banyak persoalan yang ditunjukkan banyak sekali aturan informal yang muncul untuk memenuhi tujuan interaksi formal. Artinya, untuk menghadirkan kesepakatan (polis) antara TKI dengan konsorsium asuransi diwarnai dengan kesepakatan informal lainnya, baik diantara calon TKI dengan PPTKIS, maupun pemerintah dan konsorsium, bahkan antar konsorsium, dan konsorsium dengan PPTKIS.

Bagi pemerintah (prinsipal) yang berperan sebagai fasilitator bagi hubungan TKI dan konsorsium, masih membutuhkan koordinasi atas pengelolaan asuransi yang dilakukan konsorsium. Untuk itu, kemudahan koordinasi tidak pernah ditemui oleh pemerintah (sesuai identifikasi sebelumnya), maka ketidakterusterangan konsorsium dalam melaporkan tiap informasi terkait pengelolaan asuransi dianggap pemerintah sebagai upaya konsorsium (agent) dalam mencari keuntungan bagi dirinya sendiri. Kondisi ini memunculkan biaya transaksi yang semakin besar, mengikuti perilaku opportunistik konsorsium asuransi.Karena semakin tinggi peluang perilaku opportunistik maka semakin besar pula biaya transaksi yang timbul. Sedangkan di sisi lain bagi pemerintah, biaya tetap saja dikeluarkan untuk melakukan negosiasi atas kontrol dan pengawasan kerja konsorsium asuransi sebagai upaya perlindungan terhadap TKI.

Kaitan antara sikap opportunistik yang dimiliki konsorsium asuransi atau bahkan dimiliki aktor lain selain konsorsium asuransi, misalnya PPTKIS dengan kemunculan biaya dapat ditelusuri karena munculnya ketidaksempurnaan aturan interaksi. Apalagi aturan dalam berinteraksi yang terjadi banyak aturan yang tidak mengikat (informal), baik antara TKI dengan PPTKIS, maupun dengan konsorsium asuransi. Pada dasarnya memang tidak ada aturan yang sempurna mutlak, sebab hubungan relasional antar aktor yang terlibat memiliki rasionalitas yang terbatas. Dan adanya ketidaksempurnaan informasi semakin memicu biaya. Meskipun demikian, keberadaan aturan tetap menjadi relevan karena sebagai payung tindakan tiap aktor yang bersepakat.Di samping itu, aturan yang disepakati juga tetap relevan karena dapat membuka kemungkinan terjadinya upaya perbaikan secara terus menerus. Namun, perbaikan ini akan menimbulkan banyak biaya, disebabkan dalam prosesnya melalui kelengkapan secara prosedural dan memakan waktu. Artinya, terdapat keterpaksaan yang harus dilakukan untuk melaksanakan kesepakatan walaupun ada biaya yang harus dikeluarkan. Jadi, implikasi ekonomi pada lingkungan kelembagaan sangat relevan dengan biaya (finansial) yang harus dikeluarkan oleh calon TKI/TKI dan pemerintah.

Sedangkan bagi konsorsium asuransi dan PPTKIS berada pada situasi yang menguntungkan. Mereka diuntungkan dengan ketidaksetaraan informasi, dan mereka yang memiliki lebih banyak informasi, sehingga kekuasaan dominasi berada pada mereka. Kondisi inilah yang menyebabkan seringkali, mereka melakukan beberapa tindakan yang opportunis (mencari keuntungan sendiri). Karena menurut Williamson (1996) bahwa individu yang berperilaku opportunis telah menggunakan informasi yang dimiliki untuk memenuhi ambisi pribadi dalam tiap transaksi yang dilaluinya. Bahkan dalam pengelolaan asuransi, konsorsium asuransi memiliki informasi yang tidak terbatas mengenai objek transaksi (yang dimiliki PPTKIS dan 
pemerintah), namun juga memiliki informasi sepanjang interaksi sampai pada batas negosiasi dan pengambilan keputusan.

Dengan realitas demikian, dapat dipahami bahwa kerangka perlindungan asuransi TKI telah membuka ruang bagi salah satu aktor yang memiliki informasi paling lengkap dan memiliki sumberdaya paling kuat (konsorsium asuransi) untuk mengambil keuntungan atas kerentanan pihak lain (TKI dan pemerintah) sematamata untuk meningkatkan kepuasannya sendiri. Potensi terjadinya moral hazard tidak dapat diatasi sekalipun saat transaksi setelah kesepakatan disetujui, dan ketidakpatuhan aturan main tetap terjadi. Potensi tersebut dilakukan oleh pihak yang memiliki otoritas kekuasaan tertinggi dalam pengambilan keputusan terkait pengelolaan asuransi TKI ini (yakni konsorsium asuransi).

Dari pemahaman tersebut, dapat dikatakan bahwa informasi yang assimetris merupakan pemicu dari timbulnya perilaku opportunis, yang berujung pada timbulnya biaya transaksi. Biaya ini di berikan pada aktor yang tidak memiliki informasi paling lengkap dan tidak memiliki sama sekali otoritas kekuasaan pengambilan keputusan, yakni TKI itu sendiri. Selain itu, hal ini mensyaratkan bahwa salah satu faktor yang mempengaruhi besarnya daya kekuatan aktor yang terlibat dalam transaksi kesepakatan adalah kemampuan aktor dalam mengelola informasi. Hubungan relasional aktor yang terlibat dalam interaksi dan transaksi yang disepakati tersebut pada akhirnya membentuk pola kekuasaan, walaupun hal tersebut diatur dalam aturan formal. Begitu juga, relasional yang dibangun konsorsium asuransi dengan PPTKIS, didalamnya memuat transaksi, dimana ada transaksi, disitulah ada biaya.

Sesuai dengan uraian temuan, maka dapat dipahami implikasi ekonomi sebagai beban ekonomi yang menjadi biaya bagi aktor, terutama TKI.Semua biaya melekat pada interaksi yang sudah dibuat antara TKI dan konsorsium asuransi sudah diverfikasi oleh pemerintah. Hal ini berdasarkan sistem dan pengaturan atas pengelolaan asuransi TKI yang mewajibkan TKI untuk membayar sejumlah uang atas premi asuransi mereka. Interaksi ini juga terkait dengan sistem dan standar penempatan TKI, yang terkait biaya penempatan yang sudah ditentukan oleh pemerintah. Selanjutnya, biaya juga berdasarkan sistem dan negara tujuan penempatan.

Masing-masing standar dan ketentuan dalam sistem yang mengatur membutuhkan biaya/finansial yang wajib dikeluarkan, terutama oleh calon TKI/TKI. Dengan demikian, implikasi ekonomi atas kesepakatan tersebut muncul dengan besarnya biaya yang ditanggung TKI, bahkan pemerintah sebagai fasilitator dan pengawas kerja konsorsium asuransi juga mengeluarkan biaya. Besarnya biaya yang dikeluarkan dalam interaksi di antara aktor tersebut ditentukan oleh atribut aktor dan juga menentukan atribut aktor, artinya masing-masing aktor akan menunjukkan perilaku rasional dan sikap opportunisnya masing-masing. Perilaku dan sikap opportunis yang ditunjukkan aktor mempengaruhi besarnya biaya yang harus ditanggung oleh aktor. Pada akhirnya, akan menentukan pola kekuasaan di antara aktor.

Asumsi yang digunakan dalam penentuan besarnya implikasi ekonomi (biaya) ini adalah perubahan lingkungan kelembagaan dan asumsi perilaku. Artinya, jika terdapat perubahan atas norma atau aturan formal yang mengatur sistem dan standar penentu biaya yang harus dikeluarkan baik biaya pengelolaan asuransi, standarisasi penempatan TKI dan aturan negara tujuan penempatan, maka biaya yang dikeluarkan aktor, terutama bagi TKI akan berkurang. Atau biaya yang dikeluarkan tergantung dari besarnya standar atau sistem pengaturan yang ada. Sedangkan asumsi perilaku juga menentukan be- 
sarnya implikasi ekonomi (biaya) ini, karena perilaku yang berada dalam lingkaran interaksi antar aktor mempengaruhi keputusan aktor dan rasionalitas dalam keputusan tersebut. Artinya, dampak potensi merugikan bagi aktor yang bersepakat akan mempengaruhi biaya yang dikeluarkan oleh salah satu aktor yakni aktor yang tidak dapat berpotensi untuk menentukan keputusan, atau rasionalitasnya terbatas. Tentu saja demikian dapat dikatakan bahwa aktor yang berada dalam rasionalitas terbatas akan mengeluarkan biaya/ efek ekonomi terbesar jika dibandingkan dengan aktor lain yang berada pada posisi terkuat. Walaupun ada aturan formal yang melingkupi lingkungan mereka, namun juga ada banyak "permainan" melalui kesepakatan informal yang juga melingkupi lingkungan kesepakatan mereka.

Seharusnya yang terjadi, proses interaksi berada pada aturan main yang sebenarnya, tidak ada pihak yang merugikan pihak lain, meskipun memang tidak terelakkan adanya ketidaksempurnaan informasi dan ketersediaan sumberdaya. Dengan demikian, proses pembuatan keputusan berlangsung secara tanggung jawab (dengan cara memuat manfaat bagi aktor yang bersepakat). Karena tipu muslihat/informasi tersembunyi tidak akan terjadi bila aktor yang bersepakat menaati kesepakatan dengan komitmen yang bisa dipegang/ kredibel (Williamson dalam Yustika, 2013).

\section{Penutup}

Mengingat arti pentingnya TKI sebagai pahlawan devisa, maka perlu sebuah skema asuransi. Namun, skema asuransi ini dibuat sebagai kebijakan perlindungan, yang dilaksanakan sebagai bentuk keseriusan Pemerintah dan aktor lainnya yang terlibat dalam memberikan perlindungan. Asuransi TKI selama ini sangat mengecewakan TKI, karena asuransi sebagai beban ekonomi. Hal ini ditunjukkan bahwa TKI mengeluarkan biaya yang sangat besar, tidak sebanding dengan manfaat yang diperolehnya. Tidak ada kejelasan pembagian keuntungan bagi TKI, proses penyelesaian klaim hanya di kantor pusat. Temuan-temuan tersebut menunjukkan kegagalan Pemerintah dalam memberikan perlindungan bagi TKI.

\section{Daftar Pustaka}

Alchian A, Demsetz H. 1972. Production, Information Costs, and Economic Organization.American Economic Review. Vol62.December : 777-795.

Azmy, Ana Shabana. 2012. Negara dan Buruh Migrant Perempuan. Menelaah Kebijakan Perlindungan Masa Pemerintahan Susilo Bambang Yudhoyono 2004-2010. Yayasan pustaka obor Indonesia. Jakarta.

Ciuca, Aurora. 2014. Strangers and Estrangement - a Human Rights View. Procedia - Social and Behavioral Sciences. Vol. 149 :180 - 183.

Delliarnov. 2006. Mencakup berbagai Teori dan Konsep yang Komperehensif. Ekonomi Politik. Erlangga. Jakarta.

Farbenblum, Bassina, Eleanor Taylor Nicholson, Sarah Paoletti. 2013. Migrant Workers'Acces To Justice Series. Akses Buruh Migran Terhadap Keadilan di Negara Asal : Studi Kasus Indonesia. Open Society Foundations. New York.

Grossman S J, Hart O D. 1983. An Analysis of the Principal-Agent Problem.Econometrica.Vol.51(1): 7-45.

ILO.2012. The strategy of the International Labour Organization, Social security for all.Building social protection floors and comprehensive social security systems. First published 2012.

Simitsia, llektra, Kallopi Kalampoukab. 2014. A New Proposal in the Public - Social Insurance System. The Case of Greece. Procedia Economics and Finance.Vol. 9:533 - 538 . 
Suharto, Edi. 2013. Kebijakan Sosial sebagai Kebijakan Publik. Penerbit Alfabeta. Bandung.

Usman. Ali. Muhammad. 2010. Asuransi TKI Melindungi atau Mencurangi?.Warta Buruh Migran, Desember 2010.

Williamson. 1996. The Mechanism of Governance. University Press. Oxford.

Yustika, Erani. 2013. Ekonomi Kelembagaan, Paradigma, Teori, dan Kebijakan. Penerbit Erlangga. Jakarta. 